\title{
Identification of caffeic acid and rutin by UHPLC MS/MS and antioxidant activity of Commelina erecta Lineu. in cell culture
}

\author{
FELIPE A.M. OTSUKA, RODRIGO B. SANTOS, LARISSA F. CHAVES, ROSANGELA S. \\ SANTOS, ADRIANO B. CHAVES FILHO, SAYURI MIYAMOTO \& HUMBERTO R. MATOS
}

\begin{abstract}
The Commelina erecta L. (C. erecta) also known as erva-de-santa-luzia is reported by local population to have medical properties against some pathological conditions. In this study, two extracts of C. erecta leaves (aqueous and ethanolic) were phytochemically analysed and evaluated for their in-vitro antioxidant activities by DPPH, TBARS, NO assays and cell viability assays. The ultra-high performance liquid chromatography followed by tandem mass spectrometry analysis showed the presence of rutin and caffeic acid in aqueous and ethanolic extract. The total polyphenols in aqueous and ethanolic extracts found were $142.7 \pm 3.0$ and $123.1 \pm 5.8 \mu \mathrm{g} / \mathrm{mL}$ of GAE, respectively. The ethanolic extract $(5 \mathrm{mg} / \mathrm{mL}$ ) inhibits TBARS by $33.8 \%$, and the aqueous extract $(5 \mathrm{mg} / \mathrm{mL}$ ) exhibited scavenger property against nitric oxide derivatives to an extent of $77.8 \%$. In cell culture, both extracts improved cell survivability under $\mathrm{H}_{2} \mathrm{O}_{2}$ induced oxidative stress. Thus, C. erecta extract is a good candidate to become a phytotherapic medicine.
\end{abstract}

Key words: Antioxidant activity, caffeic acid, Commelina erecta L., polyphenols.

\section{INTRODUCTION}

The family of plants called Commelinaceae belongs to equisetopsida class, it is native of tropical America and well distributed in tropics with about 155 genus and 500 species (Mirbel 1804). Commelina erecta L. (C. erecta) in Brazil, is popularly called erva-de-santa-luzia, and has an ethnopharmacological relevance as its leaves extract finds applications against eyes infections, skin rashes, hepatic disorders, as diuretic and antirheumatic (Alonso Paz et al. 1995, Lombardo 1983).

The oxidative stress is implicated in mediating several diseases, for instance, diabetes, neurodegenerative diseases (LópezAlarcón et al. 2014, Shi \& Pan 2012). The loss of redox balance between the production of reactive oxygen or nitrogen species and antioxidant defences cause metabolic deregulation and signalling dysfunction (Behl \& Moosmann 2002) and hence diseases. Substances able to neutralize reactive species are called antioxidants, these substances can prevent the damage to living organisms caused by reactive species (Saravanan et al. 2014). The phenolic compounds for instance are known to have antioxidant and anticancer property (Scalbert et al. 2005). However, there is a great lack of chemical information about antioxidant compounds in C. erecta.

Medicinal herbs are used worldwide as part of traditional medicine to improve health and 
decrease disease risk factors and therefore $C$. erecta leaf extracts were chosen. The goals of this study were to screen the $C$. erecta leaf extracts for antioxidant activity using in vitro assays, and to establish the active principle by ultra-high performance liquid chromatography coupled with tandem mass spectrometry (UHPLC-MS/ MS).

\section{MATERIALS AND METHODS}

\section{Plant material}

The plants were harvested in Sergipe, city of São Cristovão, Brazil, location coordinates 1058'35.7"S 37¹5'25.8"W during September 2012. They were classified by Federal University of Sergipe, herbarium and assigned the voucher number ASE 2319. The leaves were separated and washed, then air dried at ambient temperature for 48 hours, totally to obtain 122,22 g of dried leaves to prepare aqueous and ethanolic extract.

\section{Extract preparation}

\section{i. Aqueous extract}

Dried leaves (20 g) were used for extraction in a similar way to tea preparation. Briefly, infusion process started shaking dried leaves in $500 \mathrm{~mL}$ of warm water $\left(70^{\circ} \mathrm{C}\right)$ until the system reach ambient temperature $\left(25^{\circ} \mathrm{C}\right)$, in the meanwhile the mixture was stirred. The extract was filtered with qualitative filter paper and lyophilized in a TE-211 (Tecnal, Brazil), obtaining $1.78 \mathrm{~g}$ (8.9\% of yielding) of extract powder. Extract was protected from light until used for analysis.

\section{ii. Ethanolic extract}

Dried leaves (20 g) were used for ethanolic extraction. Briefly, the leaves were shaken with $600 \mathrm{~mL}$ of ethanol (90\%) at ambient temperature $\left(25^{\circ} \mathrm{C}\right)$ for 2 hours with constant mixing. The extract was filtered with qualitative filter paper and roto-evaporated in a MA-120 (Marconi, Brazil), obtaining $1 \mathrm{~g}$ (yielding 5\%) of extract powder that was protected from light.

Both extracts were resuspended in their respective extraction solutions in five different concentrations $(1-5 \mathrm{mg} / \mathrm{mL})$ and crude extract was divided for antioxidant screening, cell viability analysis and UHPLC analysis. When necessary, extract powder was stored at $-20^{\circ} \mathrm{C}$.

\section{Total phenolic determination}

Folin-Ciocalteau method (Singleton \& Rossi 1965) of phenol assay was carried out in triplicate, read in spectrophotometer at $765 \mathrm{~nm}$ and results were expressed in $\mu \mathrm{g} / \mathrm{mL}$ of gallic acid equivalent (GAE).

\section{Antioxidant activity of 2,2-diphenyl-1- picrylhydrazyl (DPPH) assay}

The assay was done following Brand-Williams method with modifications (Brand-Williams et al. 1995). Briefly, was measured through spectrophotometer the absorption of the methanolic radical 2,2-diphenyl-1-picrylhydrazyl (DPPH) solution at $515 \mathrm{~nm}$. The assay was conducted dissolving the crude extract in five different concentrations ( $1-5 \mathrm{mg} / \mathrm{mL}$ ), then $50 \mu \mathrm{L}$ of each extract solution was mixed with $2 \mathrm{~mL}$ of DPPH $90 \mu \mathrm{M}$ solution. The assay was done in quadruplicate and each sample was read with a gap of 5 minutes for a total of 15 minutes starting from 0 minutes. Butylated hydroxytoluene $(\mathrm{BHT})$ solution $(1 \mathrm{mg} / \mathrm{mL})$ was used as positive control and the results were expressed as inhibition percent (IP) of DPPH radical. The IP was calculated as following: IP = $A_{\text {control }}-\left(A_{\text {sample }}-A_{\text {blank }}\right) / A_{\text {control }} * 100$. Where $A_{\text {control }}$ is the absorbance of the DPPH only measured at 20 minutes, $A_{\text {sample }}$ is the absorbance of the DPPH + sample solution measured at 20 minutes, and $A_{\text {blank }}$ is the absorbance of the solvent used. 


\section{Thiobarbituric acid reactive substances (TBARS) assay}

The assay was performed according to the method of Hartwig et al. (1993) with modifications to quantify lipid peroxidation. The supernatant was then read on spectrophotometer at $532 \mathrm{~nm}$. The assay was conducted in triplicate and the concentration of thiobarbituric acid reactive substances (TBARS) was calculated with the molar extinction coefficient $\left(\varepsilon=157000 \mathrm{~L} \mathrm{~mol}^{-1}\right.$ $\mathrm{cm}^{-1}$ ).

\section{Scavenging of nitric oxide}

The assay was done following Green et al. (1982) method to quantify nitric oxide derivatives (NOX, $\mathrm{x}=2$ or 3 ) with modifications. Briefly, a solution of sodium nitroprusside (SNP) $5 \mathrm{mM}$ in phosphate buffer $0.1 \mathrm{M}(\mathrm{pH}=7.0)$ was incubated with the extract solutions to a proportion of $10 \mu \mathrm{L}$ of extract to $4 \mathrm{~mL}$ of SNP. Then, $1 \mathrm{~mL}$ of the Griess reagent (sulfanilamide 1\% in phosphoric acid $5 \%$ and $\mathrm{N}$-1-naphthyl-ethylenediamine $0.1 \%$ ) was added in the mixture and the absorbance was read at $546 \mathrm{~nm}$ for each 30 minutes for a total of 150 minutes at 25 oC. The concentration of the extract solutions ranged from $0.5-5 \mathrm{mg} /$ $\mathrm{mL}$, results were expressed as IP of NOx after 150 minutes. Assay was done in quadruplicate.

\section{Cell cultures}

Murine fibroblasts from the NCT clone 929 strain (L929 cells), originated from adipose connective tissue was used to test the aqueous extract and human lung's fibroblasts IMR-90 (ATCC ${ }^{\circledR}$ CCL-186 ${ }^{\mathrm{TM}}$ ) to test the ethanolic extract to study the protective effect of the extracts against the oxidative stress mediated by $\mathrm{H}_{2} \mathrm{O}_{2}$. The cells were incubated at $37{ }^{\circ} \mathrm{C}$ under a humid atmosphere with $5 \%$ of $\mathrm{CO}_{2}$ and cultivated in a modified media Dulbecco with Eagle medium (DMEM), glucose (1000 mg/L), L-glutamine (1000 mg/L), sodium bicarbonate $(3700 \mathrm{mg} / \mathrm{L})$, fetal bovine serum (10\%), streptomycin $(100 \mu \mathrm{g} / \mathrm{ml})$ and penicillin (100 units/mL).

\section{Cell viability by 3-(4, 5-dimethylthiazol-2-yl)-2, 5-diphenyltetrazolium bromide (MTT) assay}

The cellular viability under oxidative stress by hydrogen peroxide was based on work done by Denizot \& Lang (1986). Groups were divided as: Control (treated with phosphate buffer), $\mathrm{H}_{2} \mathrm{O}_{2}$ (Treated only with hydrogen peroxide 100 $\mu \mathrm{M})$, Caffeic acid (treated with caffeic acid 50 $\mu \mathrm{M}$ under $\mathrm{H}_{2} \mathrm{O}_{2}$ treatment), and three groups of extracts called "Aq/Et Com" (aqueous or ethanolic commelina extracts: 0.25, 0.5, and 1 $\mathrm{mg} / \mathrm{mL}$ ) treated with $\mathrm{H}_{2} \mathrm{O}_{2}$. The cells L-929 were cultivated in a 96 wells culture plate with $2 \times$ $10^{4}$ cells/well, for 24 hours. Then, the tested cells were washed and incubated with the extract's solutions done in DMEM for 2 hours and the control cells were washed and treated with phosphate buffer solution. After that, the cells were washed and incubated with $100 \mu \mathrm{M}$ of $\mathrm{H}_{2} \mathrm{O}_{2}$ for 10 minutes. The cells were washed and $188 \mu \mathrm{L}$ of DMEM plus $112 \mu \mathrm{L}$ of 3-(4,5-301 dimethylthiazol-2-yl)-2-5-diphenyl tetrazolium bromide (MTT) (5 mg/mL) were added and incubated for 2 hours. The medium was removed and the precipitated (formazan) was solubilized in $150 \mu \mathrm{L}$ of sodium dodecyl sulfate (SDS) $50 \%$ and $150 \mu \mathrm{L}$ of dimethylformamide ( $\mathrm{pH}$ 4.8). The assay was done in quadruplicate and read at 595 $\mathrm{nm}$ in spectrophotometer (LIBRA S60, Biochrom).

\section{UHPLC-MS/MS analysis}

Aqueous extract powder was resuspended using $100 \mathrm{mg}$ of extract per $\mathrm{mL}$ of water and pre-treated with a clean-up method described by Vinson et al. (2001) with modifications. Water soluble phenols were determined using $0.1 \mathrm{~mL}$ of extract solution in a $0.5 \mathrm{~mL}$ mixture containing $50 \%$ methanol/water. After an extraction time of 3 hours under $90^{\circ} \mathrm{C}, 1 \mathrm{~mL}$ of methanol was added 
and the samples were centrifuged at $2500 \mathrm{~g}$ for $10 \mathrm{~min}$. The supernatant was filtered with a 0.22 $\mu \mathrm{m}$ Durapore ${ }^{\circledR}$ (PVDF) and $5 \mu \mathrm{L}$ were injected in the UHPLC/ ESI-TOFMS system.

The chemical characterization was performed by ESI-TOFMS (Triple TOF 6600, Sciex, Concord, US) interfaced with an ultra-high performance liquid chromatography (UHPLC Nexera, Shimadzu, Kyoto, Japan). The samples were loaded into a Phenomenex Kinetex ${ }^{\circledR}$ (C18 column, $2.6 \mu \mathrm{m}, 2.1 \mathrm{~mm}$ i.d. $\times 100 \mathrm{~mm}$ )

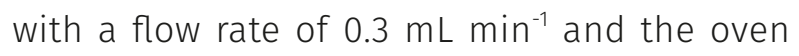
temperature maintained at $25^{\circ} \mathrm{C}$. For reversephase LC, mobile phase A consisted of water, while mobile phase $B$ composed of acetonitrile. Mobile phases A and B contained formic acid (at a final concentration of $0.05 \%$ ) for experiment performed in negative ionization mode. The linear gradient during analysis was as follows: from 10 to $36.7 \%$ B over the first 5 min., from 36.7 to $90 \%$ B during 5-9 min, hold at 90\% B from 9-14 min., decreased from 90 to $10 \%$ B during 14-15 min., and hold at 10\% B from 15-20 min.

The MS was operated in negative ionization mode, and the scan range set at a mass-tocharge ratio of 100-1000 Da. Data acquisition using Analyst ${ }^{\circledR}$ 1.7.1 was performed with 100 ms acquisition time for MS1 scan and 25 ms acquisition time to obtain the MS2 of rutin and caffeic acid. An ion spray voltage of $-4.5 \mathrm{kV}$ and the cone voltage at $-80 \mathrm{~V}$ were set to analysis. Additional parameters included curtain gas set at 25 psi, nebulizer and heater gases at 50 psi and interface heater of $450{ }^{\circ} \mathrm{C}$. The post-acquisition MRM-like data was used for quantification of rutin $[\mathrm{M}-\mathrm{H}]^{-}(\mathrm{m} / \mathrm{z} 609.1 \rightarrow 300.0276)$ and caffeic acid $[\mathrm{M}-\mathrm{H}]^{-}(\mathrm{m} / \mathrm{z} 179.0 \rightarrow$ 135.0452). The collision energies used for each compound were $-45 \mathrm{eV}$ for rutin and $-20 \mathrm{eV}$ for caffeic acid. The MS/MS data was analyzed with PeakView ${ }^{\oplus}$.

\section{Statistical analyses}

Student's t-test and ANOVA followed by Bonferroni post-test were used to evaluate the significant difference among the means of the different concentrations and the controls, analysis was performed using GraphPad Prism version 5.0 for Windows. The results were expressed as mean \pm standard deviation. Linear correlation coefficient (Pearson productmoment) was calculated to measure linearity between two variables. Different statistical significance was defined as $p<0.05$.

\section{RESULTS AND DISCUSSION}

Many studies involving polyphenols have shown their antioxidant potential, therefore these compounds can modulate positively against some deleterious processes such as hepatical cirrhosis and cancer (Morry et al. 2017). Table I represents the screening of antioxidant role of both extracts (aqueous and ethanolic). The concentration of polyphenols expressed as gallic acid equivalents (GAE) of the aqueous and ethanolic extract for the tested concentrations $(1-5 \mathrm{mg} / \mathrm{mL})$ increased from $29.7 \pm 0.6$ to 142.7 $\pm 3.0 \mu \mathrm{g} / \mathrm{mL}$ linearly $(r=0.998)$ and $45.4 \pm 0.7$ to $123.1 \pm 5.8 \mu \mathrm{g} / \mathrm{mL}(r=0.998)$ of GAE respectively. Phenolic compounds, which include a broad class of known antioxidants such as flavonoids and phenolic acids, perform their action through reduction of several oxidizing agents. Thus, the total phenolic content of an extract is an estimative of its reducing power against free radicals, which mechanism of action relies on the donation of the hydrogen from the phenol group, and self-stabilization through the aromaticity (Yehye et al. 2015).

Regarding the DPPH scavenging, both extracts were able to reduce DPPH formation in a concentration dependent manner, but 
Table I. Antioxidant activity screening of the aqueous and ethanolic extract from C. erecta leaves.

\begin{tabular}{|c|c|c|c|c|c|c|c|c|}
\hline \multirow{2}{*}{$\begin{array}{c}\text { Sample } \\
\text { Concentration }\end{array}$} & \multicolumn{2}{|c|}{$\begin{array}{l}\text { Total polyphenols } \\
\text { ( } \mu \mathrm{g} / \mathrm{mL} \text { of GAE) }\end{array}$} & \multicolumn{3}{|c|}{$\begin{array}{c}\text { DPPH } \\
\text { Inhibition Percent (\%) }\end{array}$} & \multicolumn{3}{|c|}{$\begin{array}{c}\text { TBARS } \\
(\mu \mathrm{M})\end{array}$} \\
\hline & Aqueous & Ethanolic & Aqueous & Ethanolic & BHT & Aqueous & Ethanolic & BHT \\
\hline $1 \mathrm{mg} / \mathrm{mL}$ & $29.7 \pm 0.6$ & $45.4 \pm 0.7$ & 0 & 0 & 43.0 & $5.7 \pm 0.1$ & $3.5 \pm 0.2$ & $3.4 \pm 0.1^{*}$ \\
\hline $2 \mathrm{mg} / \mathrm{mL}$ & $63.1 \pm 2.6$ & $53.0 \pm 6.8$ & $0.7 \pm 0.2$ & $0.6 \pm 0.3$ & - & $5.9 \pm 0.1$ & $3.5 \pm 0.2$ & - \\
\hline $3 \mathrm{mg} / \mathrm{mL}$ & $91.3 \pm 14.7$ & $77.8 \pm 7.2$ & $1.3 \pm 0.4$ & $1.2 \pm 0.5$ & - & $5.9 \pm 0.1$ & $3.4 \pm 0.3$ & - \\
\hline $4 \mathrm{mg} / \mathrm{mL}$ & $110.8 \pm 2.0$ & $119.7 \pm 7.4$ & $2.4 \pm 0.8$ & $2.0 \pm 0.5$ & - & $5.9 \pm 0.2$ & $3.3 \pm 0.2$ & - \\
\hline $5 \mathrm{mg} / \mathrm{mL}$ & $142.7 \pm 3.0$ & $123.1 \pm 5.8$ & $5.4 \pm 0.7$ & $4.6 \pm 0.8$ & - & $5.8 \pm 0.1$ & $3.0 \pm 0.1$ & - \\
\hline $\begin{array}{c}\text { Linear } \\
\text { coefficient }(r)\end{array}$ & 0.993 & 0.932 & 0.935 & 0.933 & - & - & - & - \\
\hline
\end{tabular}

Data are mean measurements \pm standard deviation, $n=4$. Butylated hydroxytoluene (BHT) was used as a reference antioxidant. In TBARS assay * means statistical difference between aqueous extract and BHT using t-student, $p<0.05$.

were less efficient (IP $=\sim 5 \%$ for the higher concentration) compared to the control BHT $(I P=\sim 43 \%)$, a well know antioxidant (Yehye et al. 2015). Evaluation of antioxidant activity by measuring DDPH absorbance is widely used, mainly on plant extracts to predict the respective free radical scavenger potential (Conforti et al. 2002). Chemical substances may perform antioxidant activity by different ways, such as single electron transfer (Nimse \& Pal 2015), metal ion-chelation activity (De Souza \& De Giovani 2004) and scavenging of peroxyl radicals (Sies \& Stahl 1995). The low efficiency observed in DPPH scavenging assay may came from the inability of such compounds current in the extract perform their optimal antioxidant activity, which depend on the chemical structure and solution properties ( $\mathrm{pH}$, solvent dieletric constant) (Cerón-Carrasco et al. 2010; Medina et al. 2013).

Finally, mimicking the lipid peroxidation throughout the MDA production by fatty acids oxidation within membrane cells (Janero 1990), the response against TBARS with the extracts were tested using the egg yolk as lipid matrix. The ethanolic extract did not show statistical difference from BHT group, so we presume that each of the tested concentrations possess the same potential to inhibit TBARS as the BHT control group. On the other hand, the aqueous extract did not change the TBARS levels in this assay. Aqueous extracts of plants may do not provide reliable TBARS measurements because the egg yolk is a lipid based matrix, so the phenolic compounds extracted by water are not lipophilic enough to protect against the lipid peroxidation of the egg yolk. As the ethanolic extraction contains lipophilic polyphenols that works better in lipid environment, such as lipid membranes, was seen a decrease in TBARS concentration. The advantage of lipophilic extracts in this assay has been discussed as the "polar paradox", which happen in trials to measure the oxidative damage of an emulsion system composed by oil : water (like the TBARS assay) plus polar antioxidants from aqueous extract that will be less effective than non-polar antioxidants from ethanolic extracts to prevent oxidative damage (Koleva et al. 2002).

The results of the NO (nitric oxide) scavenger activity of extracts through inhibition of NOx (nitric oxide derivatives) are shown in Table II. According to the data, both extracts possessed high inhibition potential against 
$\mathrm{NO}_{\mathrm{x}}$ formation and increased the inhibition as extract concentration rises. The maximum IP reached for ethanolic extract $(5 \mathrm{mg} / \mathrm{mL})$ was $85.6 \% \pm 1.9$ and the aqueous extract ( $5 \mathrm{mg} /$ $\mathrm{mL}$ ) reached $77.8 \% \pm 2.5$ after 150 minutes. We could not find any report of $\mathrm{C}$. erecta extracts on the evaluation of NO inhibition. Since NO is an important modulator of inflammatory process and participates in cytotoxicity pathways mediated by bacteria (Cerqueira \& Yoshida 2002), the efficient NO scavenging by the tested extracts is suggestive of their anti-inflammatory and antioxidant activity potentials.

To evaluate the antioxidant activity in cell culture the MTT method was used with L-929 and IMR-90 cells under oxidative stress induced by hydrogen peroxide (Denizot \& Lang 1986), that indirectly measures the cell viability through the conversion of the yellow MTT to an insoluble formazan salt by mitochondria. As shown in the Figure 1, both the extracts protected against the oxidative stress induced by hydrogen peroxide $\left(\mathrm{H}_{2} \mathrm{O}_{2}\right)$ by increasing the survivability of cells compared with the non-treated cells, presumably by antioxidant mechanisms like free radical scavenger. Cell damage induced by hydrogen peroxide is a model where reactive oxygen species (ROS) are formed in excess, decreasing cell viability, because $\mathrm{H}_{2} \mathrm{O}_{2}$ is a ROS and it reacts with biomolecules such as lipid membranes, proteins and DNA, resulting on cell growth impairment by stopping the replication process of the DNA and activating apoptosis pathways (Redza-Dutordoir \& Averill-Bates 2016, Soria-Valles et al. 2015).

Figure 2 shows the UHPLC-MS/MS results. Comparing peaks retention times (RT) with standards it was possible to identify caffeic acid (a) and rutin (b). Caffeic acid showed higher signal intensity in ethanolic extract. More detailed characterization of caffeic acid and rutin availability in Commelina erecta extract is shown in MS/MS analysis of the extracts. Fragmentation of the peak corresponding to caffeic acid ( $\mathrm{m} / \mathrm{z}$ 179.0) displayed a fragment corresponding to the loss of $\mathrm{CO}_{2}$ at $\mathrm{m} / \mathrm{z} 135.0452$. For rutin ( $\mathrm{m} / \mathrm{z}$ 609.1), the main fragment at $\mathrm{m} / \mathrm{z}$ 300.0287 was derived from the fragmentation of the glycosidic bond. The chromatogram profile (Fig. 2C) showed 2 clear peaks one at RT=2.9 min and the other at RT=4.1 min in the channel corresponding to caffeic acid transition $(\mathrm{m} / \mathrm{z}=$

Table II. Inhibitory effect of the ethanolic and aqueous extract from C. erecta leaves on nitric oxide scavenger assay.

\begin{tabular}{|c|c|c|c|c|}
\hline & \multicolumn{2}{|c|}{ Aqueous extract } & \multicolumn{2}{c|}{ Ethanolic extract } \\
\hline $\begin{array}{c}\text { Extract } \\
\text { concentration } \\
(\mathbf{m g} / \mathbf{m L})\end{array}$ & $\mathrm{IP}$ & $\mathrm{NO}_{x}$ concentration $(\mu \mathrm{M})$ & $\mathrm{IP}$ & $\mathrm{NO}_{x}$ concentration $(\mu \mathrm{M})$ \\
\hline 0.5 & $51.6 \pm 5.3$ & $8.7 \pm 1.9^{\star}$ & $62.8 \pm 6.6$ & $6.4 \pm 1.7$ \\
1 & $55.9 \pm 7.6$ & $7.9 \pm 1.5^{\star}$ & $74.3 \pm 6.9$ & $4.5 \pm 1.2$ \\
2.5 & $64.2 \pm 3.8$ & $6.4 \pm 0.7^{\star}$ & $83.4 \pm 3.3$ & $2.9 \pm 0.6^{\star \star}$ \\
5 & $77.8 \pm 2.5$ & $4.0 \pm 0.5^{\star}$ & $85.6 \pm 1.9$ & $2.5 \pm 0.5^{\star *}$ \\
\hline Water & - & $17.9 \pm 0.7$ & - & - \\
\hline Ethanol & - & - & $52.3 \pm 10.7$ & $8.3 \pm 2.5$ \\
\hline
\end{tabular}

Data of concentration are presented as mean \pm standard deviation $n=4$ after 150 minutes of reaction. * means statistically different between Water control group vs Aqueous extract group using t-Student $p<0.05$ and ** means statistically different between Ethanol control group vs Ethanolic extract group using t-Student $p<0.05$. 
a

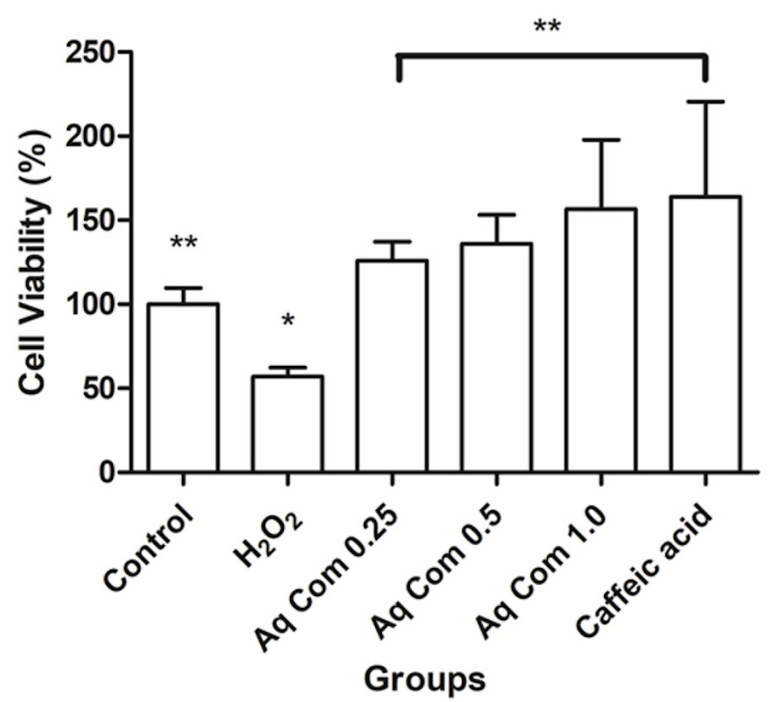

b

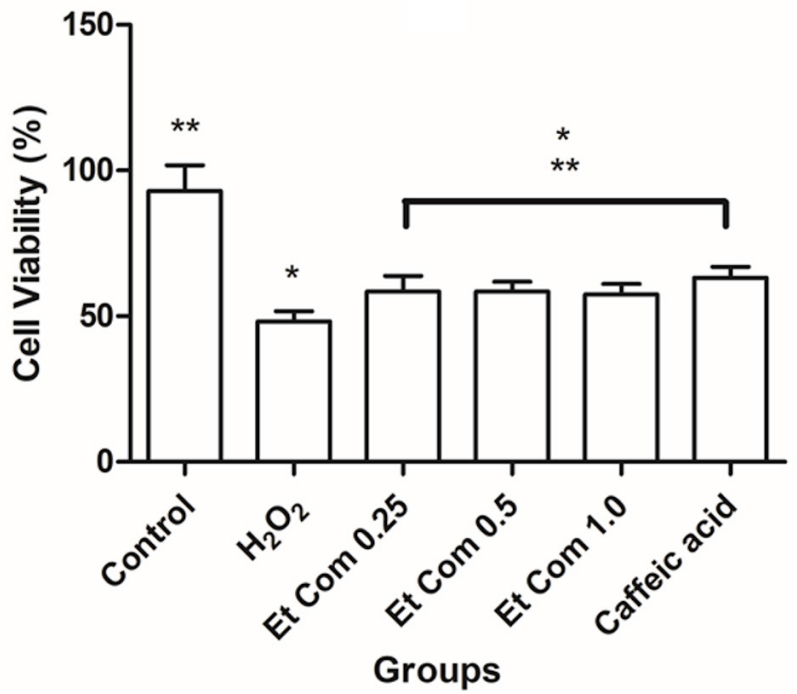

Figure 1. Cell viability by MTT assay in L-929 cells in presence of the aqueous extract of $C$. erecta leaves (a) and ethanolic extract treatment in IMR-90 cells (b). Control group = no treatment (just phosphate buffer), $\mathrm{H}_{2} \mathrm{O}_{2}$ group = treated with $\mathrm{H}_{2} \mathrm{O}_{2} 100 \mu \mathrm{M}$, Caffeic acid group = treated with caffeic acid $(50 \mu \mathrm{M})$ plus $\mathrm{H}_{2} \mathrm{O}_{2}, \mathrm{Aq}$ and Et Com groups = treated with aqueous and ethanol extract $(0.25,0.5$ and $1 \mathrm{mg} / \mathrm{mL})$ plus $\mathrm{H}_{2} \mathrm{O}_{2}$. ${ }^{*}$ Statistically different between control group $\mathrm{p}<0.05$ and $* *$ statistically difference between $\mathrm{H}_{2} \mathrm{O}_{2}$ group $\mathrm{p}<0.05$. For multiple comparisons ANOVA followed by Bonferroni's test was applied.

$179.0 \rightarrow 135.04)$ suggesting the presence of an unknown molecule similar to caffeic acid $(\mathrm{m} / \mathrm{z}$ = 135.04) but more lipophilic. Additionally, for the channel monitoring rutin $(\mathrm{m} / \mathrm{z}=609.1 \rightarrow$ 300.0276), the chromatogram profile showed a single peak at RT=3.8 min. Interestingly rutin intensity was greater in aqueous compared to ethanolic extract.

It is assumed that C. erecta extracts possess antioxidant activity primarily against NOx, the oxidized state from the free radical nitric oxide (NO) (Green et al. 1982), because the presence of caffeic acid, based on results of Table II and Figure 2. The suggested mechanism by how caffeic acid inhibits NO is not totally understood, but was shown that nitration reaction can happen at the ring and in the propanoate double bond of caffeic acid (D'ischia 2005). Recent studies have demonstrated important role of antioxidants protecting cells against oxidative stress induced by either reactive oxygen and nitrogen species (Lee et al. 2016). Caffeic acid has been reported with antinistrosative effects in Alzheimer disease and other inflammatory models (Mehrotra et al. 2011; Wang et al. 2016). The extracts tested were remarkable by effectively increasing cell viability under damage by ROS and combat NO toxicity because of the presence of polyphenols. The ability of the C. erecta extracts as an antioxidant and as an antinitrosative agent is attributed to the presence of caffeic acid (Kono et al. 1995; Pinto et al. 2015).

\section{CONCLUSIONS}

As many plants are accepted by population for medical uses, a study about their potential chemicals and their role as antioxidants is crucial for rational use. The study demonstrates 

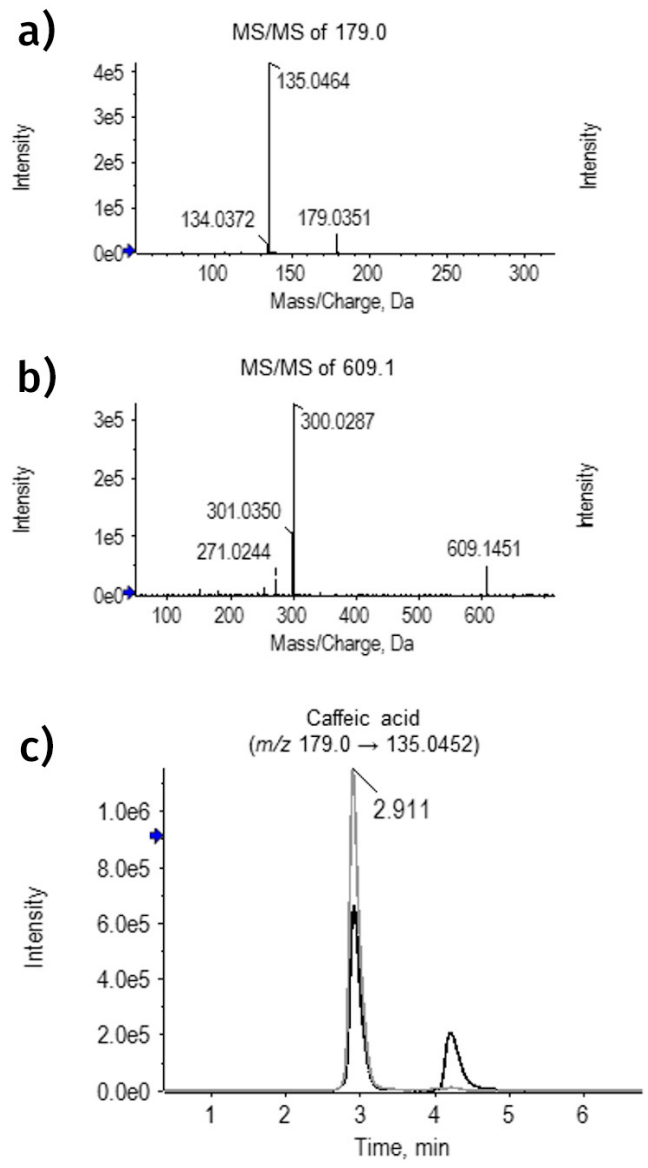

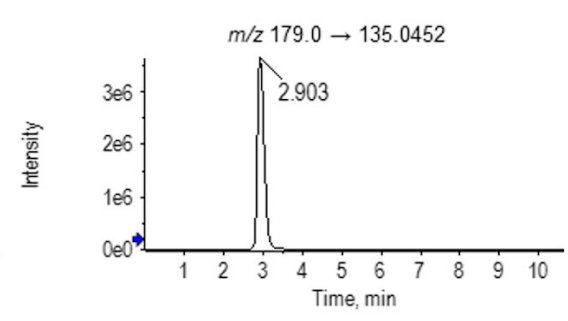

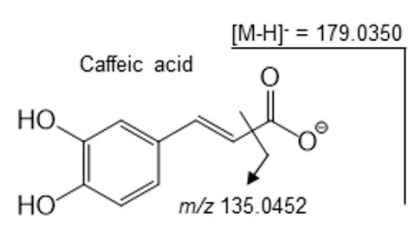
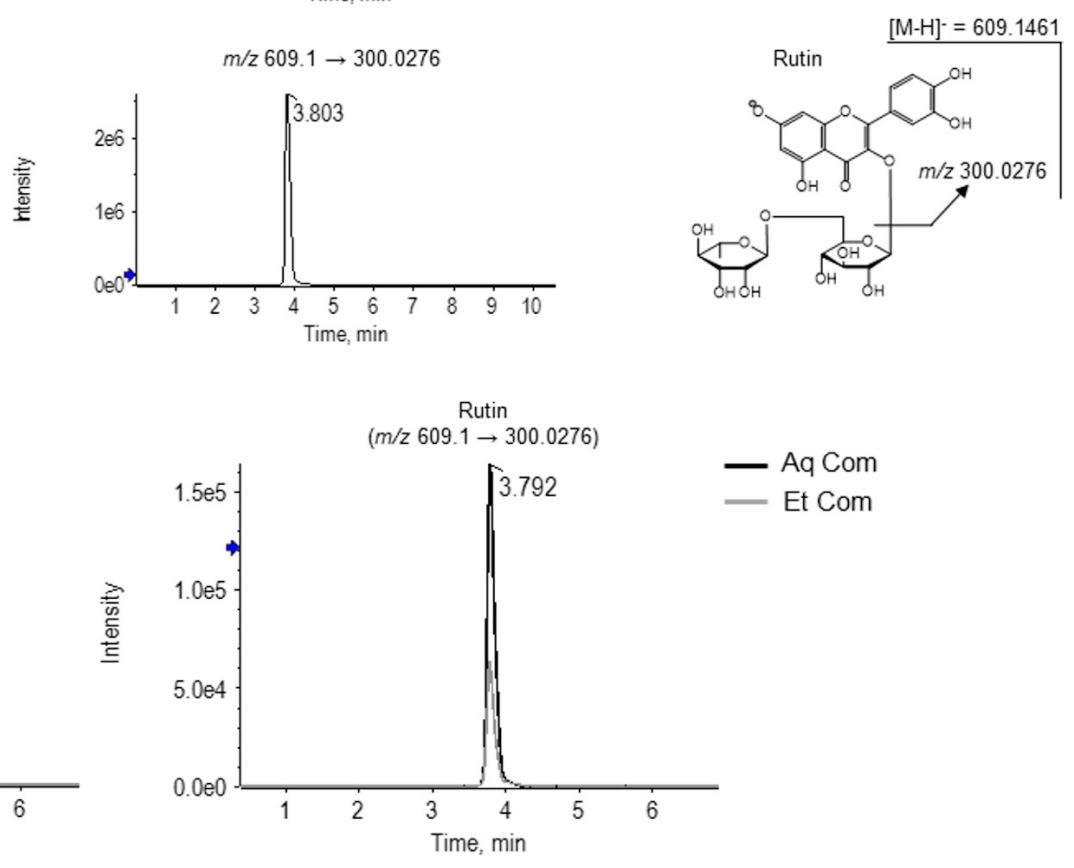

Figure 2. Mass spectra and chromatogram profile of Caffeic acid in the channel $\mathrm{m} / \mathrm{z} 179.0 \rightarrow 135.0452$ (a) and Rutin in the channel $\mathrm{m} / \mathrm{z} 609.1 \rightarrow 300.0276$ (b) identified in C. erecta extracts (c). Liquid chromatography run conditions were: column Phenomenex Kinetex ( 18 column, $2.6 \mu \mathrm{m}, 2.1 \mathrm{~mm}$ i.d. $\times 100 \mathrm{~mm}$ ) with a flow rate of $0.3 \mathrm{~mL} \mathrm{~min}{ }^{-1}$ and the oven temperature maintained at $25^{\circ} \mathrm{C}$. The collision energies used for each compound were $-45 \mathrm{eV}$ for rutin and $-20 \mathrm{eV}$ for caffeic acid.

that both extracts showed antioxidant activity against oxidative stress and NOx screening assays. Further the treatment of hydrogen peroxide challenged cell cultures with C. erecta extracts raised the cell viability. The chemical characterization of the $\mathrm{C}$. erecta extracts showed the presence of caffeic acid even in different run conditions and other substances not yet characterized. Thus, this plant has antioxidant potential to minimize risk associated with diseases that are mediated by oxidative stress.

\section{Acknowledgments}

We thank Osvaldo Andrade Santos of the Universidade Federal de Sergipe and Perinto Calafange, for kindly provided the Commelina erecta samples for analysis, and Lydia F. Yamaguchi and Prof. Masuo J. Kato from the Institute of Chemistry, University of Sao Paulo for providing caffeic acid and rutin standards. The authors are grateful for the technical and financial support from the Conselho Nacional de Desenvolvimento Científico e Tecnológico (CNPq); Instituto Nacional de Ciência e Tecnologia de Processos Redox em Biomedicina (INCT - REDOXOMA). 


\section{REFERENCES}

ALONSO PAZ E, CERDEIRAS MP, FERNANDEZ J, FERREIRA F, MOYNA P, SOUBES M, VÁZQUEZ A, VERO S \& ZUNINO L. 1995. Screening of Uruguayan medicinal plants for antimicrobial activity. J Ethnopharmacol 45: 67-70.

BEHL C \& MOOSMANN B. 2002. Oxidative nerve cell death in Alzheimer's disease and stroke: Antioxidants as neuroprotective compounds. Biol Chem 383: 521-536.

BRAND-WILLIAMS W, CUVELIER ME \& BERSET C. 1995. Use of a free radical method to evaluate antioxidant activity. LWT - Food Sci Technol 28: 25-30.

CERÓN-CARRASCO JP, BASTIDA A, REQUENA A, ZÚÑIGA J \& MIGUEL B. 2010. A theoretical study of the reaction of $\beta$-carotene with the nitrogen dioxide radical in solution. J Phys Chem B 114: 4366-4372.

CERQUEIRA NF \& YOSHIDA WB. 2002. Óxido nítrico: revisão. Act Cir Bras 17: 417-423.

CONFORTI F, STATTI GA, TUNDI R, MENICHINI F \& HOUGHTON P. 2002. Antioxidant activity of methanolic extract of Hypericum triquetrifolium Turra aerial part. Fitoterapia 73: 479-483.

DENIZOT F \& LANG R. 1986. Rapid colorimetric assay for cell growth and survival. Modifications to the tetrazolium dye procedure giving improved sensitivity and reliability. J Immunol Methods 89: 271-277.

DE SOUZA RFV \& DE GIOVANI WF. 2004. Antioxidant properties of complexes of flavonoids with metal ions. Redox Rep 9: 97-104.

D'ISCHIA M. 2005. Nitrosation and nitration of bioactive molecules: Toward the basis of disease and its prevention. CR CHIM 8: 797-806.

GREEN LC, WAGNER DA, GLOGOWSKI J, SKIPPER PL, WISHNOK IS \& TANNENBAUM SR. 1982. Analysis of nitrate, nitrite, and [15N] nitrate in biological fluids. Anal Biochem 126: 131-138.

HARTWIG A, KLYSZCZ-NASKO H, SCHLEPEGRELL R \& BEYERSMANN D. 1993. Cellular damage by ferric nitrilotriacetate and ferric citrate in V79 cells: interrelationship between lipid peroxidation, DNA strand breaks and sister chromatid exchanges. Carcinogenesis 14: 107-112.

JANERO DR. 1990. Malondialdehyde and thiobarbituric acid-reactivity as diagnostic indices of lipid peroxidation and peroxidative tissue injury. Free Radic Biol Med 9: 515-540.

KOLEVA II, VAN-BEEK TA, LINSSEN JP, DE GROOT A \& EVSTATIEVA LN. 2002. Screening of plant extracts for antioxidant activity: a comparative study on three testing methods. Phytochem Anal 13: 8-17.

KONO Y, SHIBATA H, KODAMA Y \& SAWA Y. 1995. The suppression of the $\mathrm{N}$-nitrosating reaction by chlorogenic acid. Biochem J 312: 947-953.

LEE CT, YU LE \& WANG JY. 2016. Nitroxide antioxidant as a potential strategy to attenuate the oxidative/nitrosative stress induced by hydrogen peroxide plus nitric oxide in cultured neurons. Nitric Oxide 54: 38-50.

LOMBARDO A. 1983. Flora Montevidensis. [s.l.] Intendencia Municipal de Montevideo.

LÓPEZ-ALARCÓN C, ARENAS A, LISSI E \& SILVA E. 2014. The role of protein-derived free radicals as intermediaries of oxidative processes. Biomol Concepts 5: 119-130.

MEDINA ME, IUGA C \& ALVAREZ-IDABOY JR. 2013. Antioxidant activity of propyl gallate in aqueous and lipid media: A theoretical study. Phys Chem Chem Phys 15: 13137-13146.

MEHROTRA A, SHANBHAG R, RAO-CHAMALLAMUDI M, SINGH VP \& MUDGAL J. 2011. Ameliorative effect of caffeic acid against inflammatory pain in rodents. Eur J Pharmacol 666: 80-86.

MIRBEL CFBD. 1804. Histoire naturelle, générale et particulière, des plantes. F. Dufart, v. 8, Paris, p. 177.

MORRY J, NGAMCHERDTRAKUL W \& YANTASEE W. 2017. Oxidative stress in cancer and fibrosis: Opportunity for therapeutic intervention with antioxidant compounds, enzymes, and nanoparticles. Redox Biol 11: 240-253.

NIMSE SB \& PAL D. 2015. Free radicals, natural antioxidants, and their reaction mechanisms. RSC Adv 5: 27986-28006.

PINTO IFD, SILVA RP, CHAVES-FILHO AB, DANTAS LS, BISPO VS, MATOS IA, OTSUKA FAM, SANTOS AC \& MATOS HR. 2015. Study of antiglycation, hypoglycemic, and nephroprotective activities of the green dwarf variety coconut water ( Cocos nucifera L.) in alloxan-induced diabetic rats. J Med Food 18: 802-809.

REDZA-DUTORDOIR M \& AVERILL-BATES DA. 2016. Activation of apoptosis signalling pathways by reactive oxygen species. BBA - Mol Cell Res 1863: 2977-2992.

SARAVANAN S, ARUNACHALAM K \& PARIMELAZHAGAN T. 2014. Antioxidant, analgesic, anti-inflammatory and antipyretic effects of polyphenols from Passiflora subpeltata leaves - A promising species of Passiflora. Ind Crop Prod 54: 272-280.

SCALBERT A, JOHNSON IT \& SALTMARSH M. 2005. Polyphenols: antioxidants and beyond. Am J Clin Nutr 81: 215S-217S. 
SHI YC \& PAN TM. 2012. Red mold, diabetes, and oxidative stress: A review. Appl Microbiol Biot 94: 47-55.

SIES H \& STAHL W. 1995. Vitamins E and C, beta-carotene, and other carotenoids as antioxidants. Am J Clin Nutr 62: 1315S-1321S.

SINGLETON VL \& ROSSI JA. 1965. Colorimetry of Total Phenolics with Phosphomolybdic-Phosphotungstic Acid Reagents. Am J Enol Vit 16: 144-158.

SORIA-VALLES C, OSORIO FG, GUTIÉRREZ-FERNÁNDEZ A, DE LOS ANGELES A, BUENO C, MENÉNDEZ P, MARTÍN-SUBERO J, DALEY GQ, FREIJE JM \& LÓPEZ-OTÍN C. 2015. NF-KB activation impairs somatic cell reprogramming in ageing. Nat Cell Biol 17: 1004-1013.

VINSON JA, SU X, ZUBIK L \& BOSE P. 2001. Phenol antioxidant quantity and quality in foods: fruits. J Agric Food Chem 49: 5315-5321.

WANG Y, WANG Y, LI J, HUA L, HAN B, ZHANG Y, YANG X, ZENG Z, BAI H, YIN H \& LOU J. 2016. Effects of caffeic acid on learning deficits in a model of Alzheimer's disease. Int J Mol Med 38: 869-875.

YEHYE WA, RAHMAN NA, ARIFFIN A, ABD-HAMID SB, ALHADI AA, KADIR FA \& YAEGHOOBI M. 2015. Understanding the chemistry behind the antioxidant activities of butylated hydroxytoluene (BHT): A review. Eur J Med Chem 101: 295-312.

\section{How to cite}

OTSUKA FAM, SANTOS RB, CHAVES LF, SANTOS RS, CHAVES FILHO AB, MIYAMOTO $S$ \& MATOS HR. 2020. Identification of caffeic acid and rutin by UHPLC MS/MS and antioxidant activity of Commelina erecta Lineu. in cell culture. An Acad Bras Cienc 92: e20190491. DOI 10.1590/00013765202020190491.

Manuscript received on April 26, 2019; accepted for publication on June 11, 2019

\section{FELIPE A.M. OTSUKA}

https://orcid.org/0000-0003-1868-751X

\section{RODRIGO B. SANTOS}

https://orcid.org/0000-0003-1677-9584

\section{LARISSA F. CHAVES ${ }^{1}$}

https://orcid.org/0000-0002-0484-0600

\section{ROSANGELA S. SANTOS ${ }^{1}$}

https://orcid.org/0000-0003-3546-2873

\section{ADRIANO B. CHAVES FILHO ${ }^{2}$}

https://orcid.org/0000-0002-2321-6504

\section{SAYURI MIYAMOTO ${ }^{2}$}

https://orcid.org/0000-0002-5714-8984

\section{HUMBERTO R. MATOS ${ }^{1}$}

https://orcid.org/0000-0003-3898-9515

${ }^{1}$ Federal University of Sergipe, Department of Physiology, Av. Marechal Rondon, s/n, Rosa

Elze, 49100-000 São Cristovão, SE, Brazil

${ }^{2}$ University of São Paulo, Department of Biochemistry, Institute of Chemistry, Av. Prof. Lineu Prestes, 748, Butantã, 05508-900 São Paulo, SP, Brazil

Correspondence to: Humberto Reis Matos

E-mail:hrmatos10@hotmail.com

\section{Author contributions}

Otsuka FAM, Filho ABC and Matos HR designed the research. Filho ABC, Santos RB, Santos RS, Chaves LF and Miyamoto $S$ characterized the phytochemical species. Otsuka FAM and Filho ABC did the antioxidant assays. Otsuka FAM, Santos RS and Matos HR wrote and contributed in reviewing the manuscript.

\section{(cc) BY}

